\title{
Tracing the role of human civilization in the globalization of plant pathogens
}

\author{
Alberto Santini $\mathbb{1}^{1} \cdot$ Andrew Liebhold ${ }^{2} \cdot$ Duccio Migliorini ${ }^{1,4} \cdot$ Steve Woodward ${ }^{3}$
}

Received: 13 May 2017 / Revised: 27 October 2017 / Accepted: 9 November 2017 / Published online: 12 January 2018

(C) International Society for Microbial Ecology 2018

Co-evolution between plants and parasites, including herbivores and pathogens, has arguably generated much of Earth's biological diversity. Within an ecosystem, coevolution of plants and pathogens is a stepwise reciprocal evolutionary interaction: epidemics result in intense selection pressures on both host and pathogen populations, ultimately allowing long-term persistence and ecosystem stability. Historically, plants, and pathogens evolved in unique regional assemblages, largely isolated from other assemblages by geographical barriers. When barriers are broken, non-indigenous pathogenic organisms are introduced into new environments, potentially finding suitable hosts lacking resistance genes and environments favouring pathogenic behavior; this process may result in epidemics of newly emerging diseases. Biological invasions are tightly linked to human activities and have been a constant feature throughout human history. Several pathways enable pathogens to enter new environments, the great majority being human mediated.

The fossil record provides evidence that diseases commonly affected plants some 250 million years ago [1]. The recurrence of wheat rust outbreaks is reported by Roman

Electronic supplementary material The online version of this article (https://doi.org/10.1038/s41396-017-0013-9) contains supplementary material, which is available to authorized users.

Alberto Santini

alberto.santini@cnr.it

1 Institute for Sustainable Plant Protection-C.N.R., Via Madonna del Piano, 10, 50019 Sesto fiorentino, Italy

2 US Forest Service Northern Research Station, Morgantown, WV 26505, USA

3 Department of Plant and Soil Science, Institute of Biological and Environmental Sciences, University of Aberdeen, Cruickshank Building, Aberdeen AB24 3UU, UK

4 Present address: Department of Microbiology and Plant Pathology, Forestry and Agricultural Biotechnology Institute (FABI), University of Pretoria, Pretoria, South Africa authors, such as Cicero, Varro, and Columella (2100-1950 BP). Rust outbreaks were so feared that there was a god/ goddess of rust (Robigus/Robigine) to whom processions, sacrifices and feasts were dedicated in order to prevent crop destruction.

During the last 200 years the incidence of plant diseases has increased exponentially in terms of both numbers and severity [2]. Alien pathogen introductions can lead to novel host-pathogen associations or novel pathogen-pathogen combinations, with no previous co-evolutionary history.

Why are so many invasive plant pathogens now appearing? The aim of this paper is to increase understanding of the means of introduction and spread of these pathogens, which, as with most invasive species, can be traced to human behavior, societal development, technological change, and geopolitical trends. We strongly believe that reviewing historical developments enhances our ability to anticipate future developments.

\section{Prehistory}

Limited information exists about the impact and spread of plant diseases before the onset of major human migrations, although some evidence suggests that pathogens played an active role in shaping the composition of prehistoric forests and other vegetation [3]. Pollen analysis from the mid Holocene suggests two catastrophic declines occurred in Northern Hemisphere forests: a hemlock (Tsuga) decline in eastern North America and an elm (Ulmus) decline in western, central, and northern Europe. Decline of Tsuga spp. was recorded at 60 sites and dated around 5500 BP [4], while elm decline occurred 6347-5281 BP based on a comprehensive review of 139 dated sites (see [5] and references therein). Both declines are characterised by the same specific features, such as strong synchrony of events over wide regions (Eastern North America and central, north-west Europe); rapidity of the decline; long periods in which these trees were largely absent. These features 


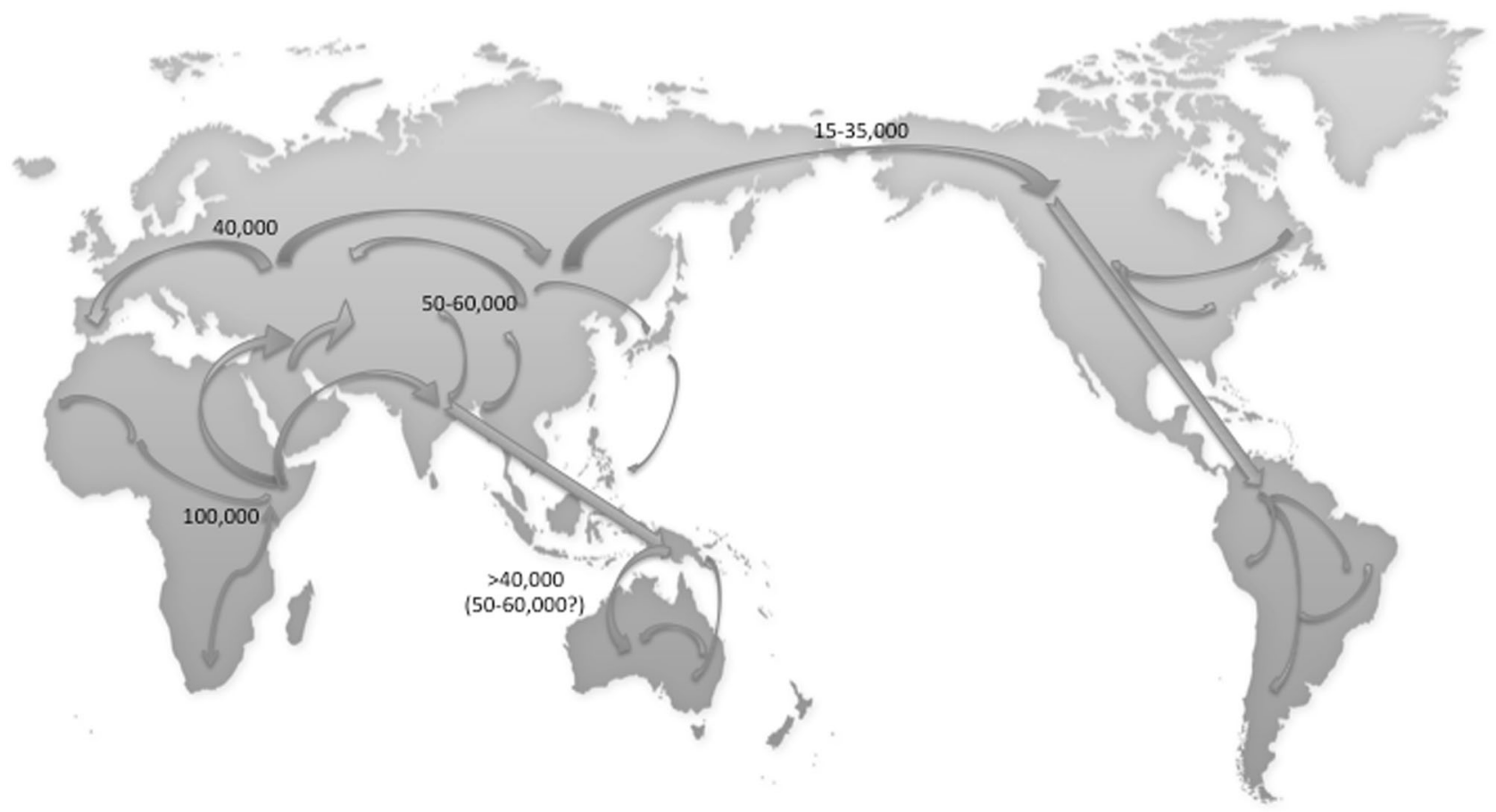

Fig. 1 Migrations of modern Homo sapiens (Adapted by permission from Macmillan Publishers Ltd: [Nature Genetics]([8]. The application of molecular genetic approaches to the study of human evolution 33:266-275), copyright 2003

suggest an invasion by a non co-evolved pathogen that eliminated the majority of hosts. The eventual re-emergence of these tree species may have been associated with a gradual development of resistance. Mid-Holocene pollen records associated with these events resemble those arising during modern epidemics of forest pathogens, including chestnut blight and Dutch elm disease (see [5] and references therein).

In addition to these massive declines, evidence exists of forest declines at more local or regional levels, ranging from temporary decreases in tree species richness, to full extinctions of specific tree taxa appearing in the Holocene pollen stratigraphy. Although many different, and sometimes contrasting, hypotheses have been advanced for the causes of these declines, most recent accounts [5] adopt a multi-factor hypothesis in which disease pandemics likely played a role along with climate changes and impacts from human activities.

\section{A starting date}

Though early intercontinental raft voyages and migrations over land bridges could have transported certain organisms, for most purposes, we can consider the starting point for plant pathogen invasions to coincide with the "Columbian Exchange", $1500 \mathrm{CE}$, which marked the beginning of large-scale human movement between Europe and the
Americas [6]. This time corresponded with initial European colonial activities which often involved trans-oceanic movement of plants and animals for cultivation in colonies, for consumption in Europe [6] and for collection of botanical specimens aboard ships. Maize, Zea mays, for example, was probably initially domesticated via hybridization of native species in the Balsas River Valley of southcentral Mexico by indigenous people [7]. As part of the Columbian Exchange it was brought to Europe in the 1500s and ultimately distributed further for cultivation in Asian and African colonies.

For these reasons invasion biologists use 1500 to divide alien plants in Europe into "archaeophytes", introduced before 1500, and "neophytes" introduced later. However, it is widely recognized that the spread of plants and their associated pathogens began much earlier.

\section{Human migrations}

Human migrations $\sim 85,000$ years BP likely caused the earliest spread of invasive species following the migration of Homo sapiens out of central Africa [8] (Fig. 1). Europe, for example was colonized between 9000 and $4500 \mathrm{BP}$ by Neolithic farmers, moving from the Fertile Crescent of Mesopotamia. Indigenous populations settled in North America after crossing the Bering Strait to Alaska during milder periods in the midst of the last ice age (15000-14000 
BP). Expanding Neolithic farming cultures probably carried plant material over considerable distances [9]. In addition, transport by sea began as far back as the Pleistocene (2588000 to $11700 \mathrm{BP}$ ).

The earliest archaeological evidence of maritime trade between Mesopotamia and the Persian Gulf was dated to the seventh and eighth millennia BP [10]. Though not impossible, extraction of fungal DNA from archaeological artifacts is challenging and, to our knowledge, there are few reports of such analyzes. However, it can be speculated that seed-borne fungi survived long periods of transport and storage, at least as long as the useful life of the seed [11]. Dark and Gent [1] suggest that the increased incidence of plant diseases during the late Iron Age and Roman periods could have been due to increasing trade in seeds, especially within the Roman Empire.

Humans have a long history of migrations and conquests during which select plants and animals were deliberately introduced to new global regions for domestication. For example, so-called English elm (Ulmus procera Salisb.) was introduced to Britain by the Romans for use in vineyards [12]. The largest Euro-Asian chestnut (Castanea sativa Mill.) glacial refuge is in the Caucasian-Armenian area. By the $11-9^{\text {th }}$ century BP humans were cultivating chestnuts between the Caspian and Black Sea. Chestnut cultivation readily spread from Asia Minor to Greece and the Balkans. The Romans quickly discovered the practical potential of chestnut cultivation and, since the first Century, Italy has been the European centre of chestnut culture [13]. A number of crop species including cereals, legumes and trees, such as tamarind and baobab were moved from Africa to the Indian subcontinent during prehistory [14]. Humans have long moved plants both to satisfy food needs, and also for ornamental purposes (Supplementary Material S1).

Nearly every individual of any wild-plant species can be expected to host hundreds of species of endophytic and plant pathogenic fungi, so it is certain that many fungal species have accompanied human movements of plants. For centuries, the time taken to travel long distances probably limited survival of potentially harmful propagules of many invasive pathogen species, but increasing speed of transport has improved the probability of propagule survival, sometimes with disastrous consequences for invaded ecosystems. For example, wheat has been cultivated in Europe and China since 6000-7000 BP; when European farmers moved into the Americas, Australia, and South Africa during the past 500 years, they introduced wheat, as well as its pathogens Phaeosphaeria nodorum and Mycosphaerella graminicola [15].

Invasive pathogen species may not be simply a consequence of human migrations: they have also forced humans to move. Plant disease outbreaks that trigged famines and, as a consequence, mass human migrations have been reported since the beginning of history and are still a major cause of this phenomenon (Supplementary Material S1).

\section{Technological progress}

Over the last 500 years, transport technology has progressively improved, decreasing trans-oceanic shipping times and facilitating the rapid movement of living plants, some of which transport plant pathogens. The S.S. Savannah, the first steamboat to cross the Atlantic Ocean (1819), represented an important milestone in transport technology and consequently in rapid plant movement. Previously, crossing the Atlantic by sailing ship required 8-12 weeks, so transport of living plants was impossible without the use of elaborate portable greenhouses, where plants needed to be potted and often re-potted during transit, using foreign soil and consequently spreading soil-borne pathogens. Continuous progress in naval and aeronautical engineering has enabled incremental improvement in the ease of transoceanic transport of live plants. This technology has allowed increases in numbers of plants transported in a single trip, resulting in an equivalent increment in viable pathogen inoculum arriving at final destinations, and increasing chances of infections occurring on new hosts.

The use of maritime containers, including refrigerated containers, has greatly facilitated large-scale movement of plants and other potential vectors of plant pathogens. The first commercial container ship, the Clifford J. Rogers, was launched in Seattle in 1955 and carried 58 metal containers. Modern container ships can carry up to 18,000 twenty-foot equivalent units (TEUs). World container port throughput was estimated at 651.1 million TEUs in 2013 ([16]; Fig. 2). International commerce in agricultural products, has increased fourfold from US\$ 414,723 million in 1990, to US\$ 1,765,405 million in 2014 (www.wto.org/sta tistics).

Among agricultural products, imports of live plants probably represent the most important pathway for transport of plant pathogens [2, 17]. Given advances in transport technologies, a complex network of global commerce in live plants has developed (Fig. 2). Favorable climates and labor costs provide incentives for production of many types of plants in tropical regions. Billions of plants consumed in the North America are produced in Central America, and Europe receives large numbers of plants from Africa and Asia (Fig. 3).

\section{Geopolitics and regulation of trade}

Legislation limiting plant diseases was born $>300$ years ago in France where laws were enacted requiring destruction of 


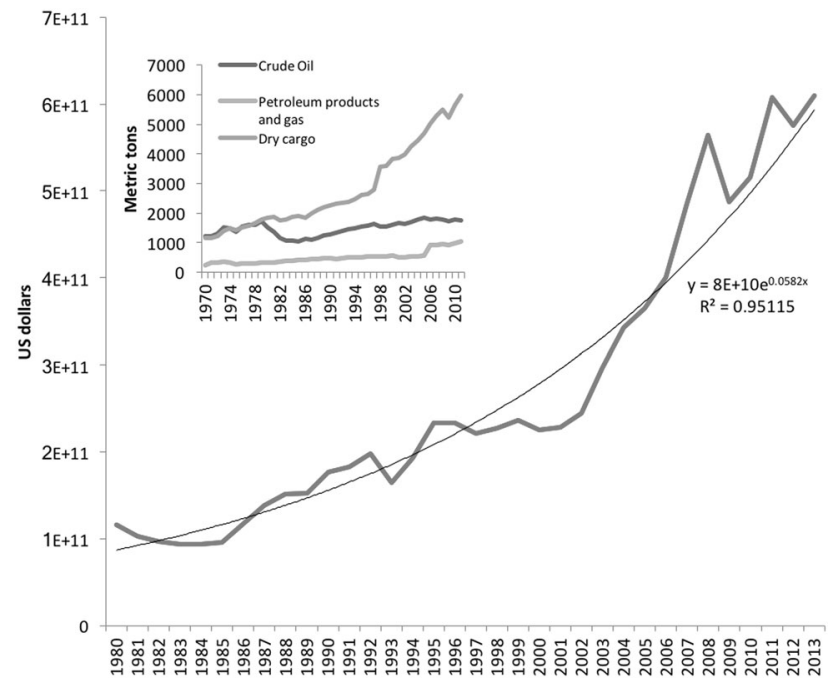

Fig. 2 Trend of European agricultural imports per year (1980-2014) expressed in USD [18]. In the box: World seaborne trade by type of cargo per year (1970-2011). Plants fall into the dry cargo category (UNCTAD, statistics 2014, unctad.org)

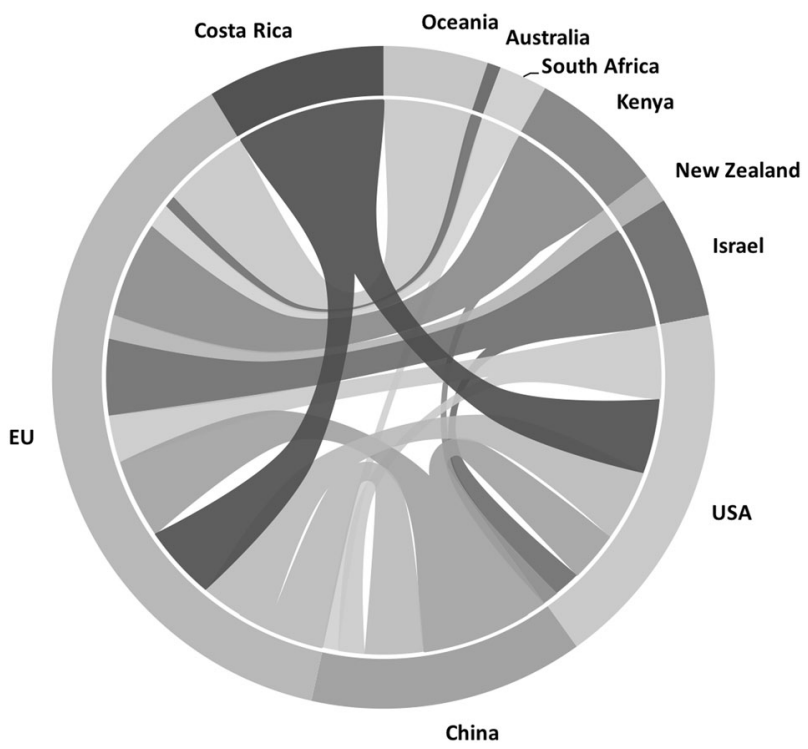

Fig. 3 Trade of plants and plant parts among principle trading countries.For each country flow widths are proportional to 2015 import and export values. Colors correspond to exports from a single country, coded by the color of the outer band. Imports are represented by different colors flowing into each country (Commodity code 0602: Live trees, including roots, cuttings, slips and mushroom spawn). Source UN Comtrade Database http://comtrade.un.org/

barberry (Berberis spp.) to control the spread of stem rust in wheat. Prior to the mid-1800s, however, there was little recognition of the potential dangers associated with accidental movement of plant pathogens on live plants and other objects. The first attempt at regulating international movement of plants took place in Europe in 1878, as a reaction to massive damage to the viticulture industry caused by the grape Phylloxera; seven European countries agreed to implement the "International Convention on Measures to be taken against Phylloxera vastatrix" (now Daktulosphaira vitifolia). The convention specified procedures for exporting countries to certify disease- and insect-free plant material for export along with plant import inspection procedures. During this era, several European countries [19], initiated their own measures to stem the flow of dangerous plant pests. In the USA, importation of live plants was not regulated until the passage of the Plant Quarantine Act in 1912 [20]. Previously, large numbers of live plants were imported without limits and many damaging insects and plant pathogens were accidentally introduced with such shipments.

World War II represented a turning point in the global movement of plant pathogens. Allied army supplies provided a pathway for movement of at least three important forest pathogens: Seiridium cardinale; Ceratocystis platani, and Heterobasidion irregulare [2]. But it was the aftermath of the war that brought massive geopolitical changes, laying the foundation for our modern globalized economy. Economists argued for the elimination of barriers to free trade ultimately leading to the General Agreement on Tariffs and Trade (GATT) in 1948.

In addition, GATT also led to important agreements that shaped international plant quarantine policy. Unjustified quarantines placed by countries on the importation of agricultural and other goods were identified as barriers to free trade. In 1994, GATT promoted the Agreement on the Application of Sanitary and Phytosanitary Measures (the SPS Agreement), which designated standards for regulatory measures implemented by member countries for the protection of plant, animal, and human life and health. The organization recognized in the agreement as the standardsetting body for plants was the International Plant Protection Convention (IPPC), a multilateral treaty overseen by the Food and Agriculture Organization (FAO) of the United Nations.

The SPS agreement states that each country can set a desired level of risk for damaging pests associated with imports and outlines a science-based procedure for managing risk. Some countries, notably New Zealand and Australia, maintain very stringent regulations on plant imports in order to minimize risk [21]. In contrast, the European Union enforces much less strict import regulations; many plants may be imported without a permit and soil associated with plants is often allowed. The presence of soil represents a particularly significant opportunity for transport of invasive pathogens [22]. The creation of the European Union and fall of the "Iron Curtain" resulted in much more open trade among European countries. These open borders increased movement among countries, potentially increasing movement of plant pests [23]. 
Following the passage of the Plant Quarantine Act in 1912, the US Department of Agriculture implemented "Quarantine 37" in 1919, which greatly curtailed plant imports and established a system of inspection and other quarantine practices [20]. These regulations resulted in a downward trend in numbers of plant pathogen introductions during the mid $20^{\text {th }}$ Century [20]. The trend was the opposite in Europe-i.e., increasing rates of establishment [2]-suggesting that the 1912 Quarantine Act has been reasonably effective in reducing numbers of new introductions to the USA.

The IPPC aims to harmonize phytosanitary measures among countries. Nevertheless, some countries lack adequate financial recourses necessary for implementing strict plant quarantine regulations, which poses a risk even to countries that maintain high quarantine standards. Countries with more "porous" borders serve as bridgeheads where pathogens may establish, become abundant and then invade other world regions [24].

Another significant problem facing effective plant quarantine programs is the high percentage of invasive pathogens of unknown origin [2, 25]. A major problem in managing invasion pathways utilized by fungi and Oomycetes is the difficulty in recognizing organisms at the species level. Many 'new' species are cryptic, resembling already known species, but with minor genetic differences which may create considerably higher virulence when exposed to host plants. The extent of this problem increases when the pathogens are endophytic or have an extended latent period before causing symptoms [26].

Certain pathogen invasion pathways can be directly identified. For example, good evidence exists that Karnal bunt of wheat entered the United States across the land border with Mexico, inadvertently transported in private automobiles, trucks, and railway cars rather than with commercial cargo [27]. However because of the difficulty in identifying pathogens and the characteristically long delay between pathogen arrival and discovery, invasion pathways for many species can only be inferred rather than observed.

In the USA, Europe and China, the main pathway for plant pest and pathogen introductions is by far imports of living plants [2, 17, 25]. In Australia and New Zealand, where international trade in plants is more strictly regulated, the arrival of pathogens is mainly linked to contamination of traded goods other than live plants.

The 'plants-for-planting' pathway is difficult to control for various reasons. Horticulture is a major global industry: in 2013, for example, 84,500 tonnes of live plants were imported into Europe, compared with exports of 400,000 tonnes (Eurostat Comext http://epp.eurostat.ec.europa.eu/ newxtweb). Faced with such huge volumes, only a small percentage of plants can realistically be inspected at ports of entry [17]. Moreover, markets in live plants, especially ornamentals, are constantly changing. Imported species and geographical sources for obtaining a given species can change rapidly. This problem exacerbates the risk of introducing new pests from different exotic locations.

\section{Conclusions}

Since prehistory, humans have dramatically changed their living environment, for example by exploiting natural resources until depletion, or via movement and cultivation of plant species outside their natural range. Agricultural and forestry practices frequently rely on non-indigenous plant species. This human-mediated globalization of plant ranges has steadily increased throughout the history of human civilization. The trend for globalization has consequences that reach beyond impacts on individual humans and their societies, also including impacts on ecosystems. In many parts of the world, invasions of plant pests and pathogens have transformed managed and natural areas, often with cascading effects on ecosystem services [28] as, for example, Phytophthora ramorum in UK, Ireland, and US.

This paper describes how historical developments in human civilization and geopolitics have driven trends of increasing movement and impacts of plant pathogens. Even before the modern era of globalization, technological developments and societal changes facilitated new plant disease epidemics that adversely affected society and shaped social development. It is also evident that during the modern era of globalization, we are poised to continue that trend, with potentially catastrophic effects on society and global ecosystems.

We argue here for closer integration of invasion biology with history and sociology, to significantly advance understanding of the causes of biological invasions and to limit future damage. Learning from this history it can be deduced that the solution to these increasing impacts lies not in halting the trend of globalization, which is neither realistic nor necessarily desirable, but to better capitalize on scientific knowledge. Implementation of scientifically based policies will allow globalization to proceed while simultaneously minimizing movement of plant pathogens, thus preventing further economic and ecological disasters. History is not merely a list of dates and names of famous people, but, as Cicero claimed in De Oratore "Historia vero testis temporum, lux veritatis, vita memoriae, magistra vitae, nuntia vetustatis...”. In short 'history is life's teacher'.

Acknowledgements We apologize to all those colleagues whose work was not cited because of space restrictions.

Author contributions A.S. developed the initial idea and drafted the first manuscript. All Authors contributed equally in discussions of the idea, and wrote the manuscript as a collective effort. 


\section{Compliance with ethical standards}

Conflict of interest The authors declare that they have no conflict of interest.

\section{References}

1. Dark P, Gent H. Pests and diseases of prehistoric crops: a yield 'Honeymoon' for early grain crops in Europe? Oxf J Archaeol. 2001;20:59-78.

2. Santini A, Ghelardini L, De Pace C, Desprez-Loustau ML, Capretti P, Chandelier A, et al. Biogeographical patterns and determinants of invasion by forest pathogens in Europe. New Phytol. 2013;197:238-50.

3. Davis MB (1981). Outbreaks of forest pathogens in Quaternary history. In: IV International Palynological Conference (1976-1977), Vol. 3, Birks HJB (ed.). Palaeobotanical Society: Lucknow; p. 216-27.

4. Bennett KD, Fuller JL. Determining the age of the mid-Holocene Tsuga canadensis (hemlock) decline, eastern North America. Holocene. 2002;12:421-9.

5. Waller MP. Drought, disease, defoliation and death: forest pathogens as agents of past vegetation change. J Quat Sci. 2013;28:336-42.

6. Crosby AW. Ecological Imperialism: The Biological Expansion of Europe. 2nd Edition. Cambridge, UK: Cambridge University Press; 2006. p. 900-1900.

7. Piperno DP. The origins of plant cultivation and domestication in the new world tropics: patterns, process, and new developments. Curr Anthropol. 2011;52:S453-S470.

8. Cavalli-Sforza LL, Feldman MW. The application of molecular genetic approaches to the study of human evolution. Nat Genet. 2003;33:266-75.

9. Diamond J, Bellwood P. Farmers and their languages: the first expansions. Science. 2003;300:597-603.

10. Carter R. Boat remains and maritime trade in the Persian Gulf during the sixth and fifth millennia se. Antiquity. 2006;80:52-63.

11. Maude RB. Seedborne Diseases and Their Control: Principles and Practice. Wallingford, Oxon., UK: CAB International; 1996.

12. Gil L, Fuentes-Utrilla P, Soto A, Teresa Cervera M, Collada C. English elm is a 2000-year-old Roman clone. Nature. 2004:431:1053.

13. Adua M. The sweet chestnut throughout history from the Miocene to the Third Millennium. Acta Horticul. 1999;494:29-36.

14. Bell KL, Rangan H, Kull CA, Murphy DJ. The history of introduction of the African baobab (Adansonia digitata, Malvaceae:
Bombacoideae) in the Indian subcontinent. R. Soc. Open Sci. 2015;2:150370. http://dx.doi.org/10.1098/rsos.150370

15. Stukenbrock EH, Banke S, McDonald BA. Global migration patterns in the fungal wheat pathogen Phaeosphaeria nodorum. Mol Ecol. 2006;15:2895-904.

16. Clarkson Research Services (2014). Container Intelligence Monthly. June.

17. Liebhold AM, Brockerhoff EG, Garrett LJ, Parke JL, Britton KO. Live plant imports: the major pathway for forest insect and pathogen invasions of the US. Front Ecol Environ. 2012;10:135-43.

18. United Nations Conference on Trade and Development, Statistics 2014. unctad.org.

19. MacLeod A, Pautasso M, Jeger MJ, Haines-Young R. Evolution of the international regulation of plant pests and challenges for future plant health. Food Security. 2010;2:49-70.

20. Liebhold AM, Griffin RL. The legacy of charles marlatt and efforts to limit plant pest invasions. Am Entomol. 2016;62:218-27.

21. Eschen R, Britton K, Brockerhoff E, Burgess T, Dalley V, Epanchin-Niell RS, et al. International variation in phytosanitary legislation and regulations governing importation of plants for planting. Environ Sci Policy. 2015;51:228-37.

22. Migliorini D, Ghelardini L, Tondini E, Luchi N, Santini A. The potential of symptomless potted plants for carrying invasive soilborne plant pathogens. Divers Distrib. 2015;21:1218-29.

23. Roques A, Auger-Rozenberg MA, Blackburn TM, Garnas J, Pysek P, Rabitsch W, et al. Temporal and interspecific variation in rates of spread for insect species invading Europe during the last 200 years. Biol Invasions. 2016;18:907-20.

24. Early R, Bradley BA, Dukes JS, Lawler JJ, Olden JD, Blumenthal $\mathrm{DM}$, et al. Global threats from invasive alien species in the twenty-first century and national response capacities. Nat Com. 2016;7:12485.

25. Xu H, Ding H, Li M, Qiang S, Guo J, Han Z, et al. The distribution and economic losses of alien species invasion to China. Biol Invasions. 2006;8:1495-1500.

26. Sakalidis ML, Slippers B, Wingfield BD, Hardy GEStJ, Burgess TI. The challenge of understanding the origin, pathways and extent of fungal invasions: global populations of the Neofusicoccum parvum-N. ribis species complex. Divers Distrib. 2013;19:873-83.

27. Marshall D, Work TT, Cavey JF. Invasion pathways of Karnal bunt of wheat into the United States. Plant Dis. 2003;87:999-1003.

28. Lovett GM, Weiss M, Liebhold AM, Holmes TP, Leung B, Lambert KF, et al. Nonnative forest insects and pathogens in the United States: Impacts and policy options. Ecol Appl. 2016;26:1437-55. 